\title{
KONSEP KEBEBASAN BERAGAMA DALAM ISLAM DAN KRISTEN
}

\author{
Tri Yuliana Wijayanti \\ Tempel RT 3/RW.7 Banyuanyar, Banjarsari Surakarta Jawa Tengah \\ E-Mail: el_iyana_247@yahoo.com
}

\begin{abstract}
This research aims to identify and explain matters related to academic problems, namely: first, understand the formulation of religious freedom in the Islamic religion and religious freedom in the formulation of the Christian religion. Second, understand the difference and points alignment of religious freedom contained in Islam and Christianity. This study was a qualitative research with religious knowledge as the scope of its research and literature as a place of research (library research). The collected data is then presented descriptively by using the approach of sociology of religion. Sources of data in this study were classified into two groups, namely primary data and secondary data. The data collected by using documentation and tested the validity of test data by applying confirmability (objectivity of research). The collected data were then analyzed with a comparative analysis and deductive models. Based on the analysis, researchers concluded that Islam and Christianity have their own meaning of religious freedom. Freedom of religion in Islam and Christians when studied by the method of comparative religion, it will show the differences - on the basis of the law of religious freedom, the freedom of religion, and the norms of religious freedom - and side alignment in the sensethe freedom of each individual to embrace religion according to his individual-and embodied the goals of religious freedom is to realize the inter religious harmony.
\end{abstract}

Keywords: freedom of religion; Islam; Christian

Abstrak: Penelitian ini bertujuan untuk mengetahui dan menjelaskan hal-hal yang terkait dengan problem akademik, yaitu: pertama, memahami rumusan kebebasan beragama dalam agama Islam dan rumusan kebebasan beragama dalam agama Kristen. Kedua, memahami letak perbedaan dan poin kesejajaran kebebasan beragama yang terdapat dalam dalam Islam dan Kristen. Penelitian kualitatif ini dengan ilmu agama sebagai ruang lingkup penelitiannya dan kepustakaan sebagai tempat penelitiannya (library research). Data yang didapat kemudian disajikan secara diskriptif dengan menggunakan pendekatan ilmu sosiologi agama. Sumber data dalam penelitian ini diklasifikasikan ke dalam dua golongan, yaitu data primer dan data sekunder. Data-data dikumpulkan dengan menggunakan teknik dokumentasi dan diuji validitas datanya dengan menerapkan uji confirmability (obyektivitas penelitian). Data dianalisis dengan komparatif dan deduktif. Kesimpulan, bahwa agama Islam dan Kristen memiliki pemaknaan tersendiri tentang kebebasan beragama. Kebebasan beragama dalam Islam dan Kristen ketika dikaji dengan metode perbandingan agama, maka akan terlihat sisi perbedaanyakni pada sisi dasar hukum kebebasan beragama, batas kebebasan beragama, dan norma kebebasan beragama-dan sisi-sisi kesejajaran yakni pada pengertian-kebebasan tiap individu untuk memeluk agama sesuai dengan keyakinannya masing-masing - dan tujuan dari terwujudkan kebebasan beragama yaitu mewujudkan kerukunan antar umat beragama.

Kata Kunci: kebebasan beragama; agama Islam; agama Kristen 


\section{PENDAHULUAN}

Islam dan Kristen termasuk agama dakwah atau agama misionaris, maksudnya suatu agama yang menyiarkan kebenarannya dan menjadikan orang lain memeluknya. Ideologi seorang Muslim menyakini bahwa Islam sebagai Rahmat bagi sekalian alam. Setiap Muslim memiliki tanggung jawab dalam mendakwahkan ajaran ini menurut kemampuan masing-masing dan sesuai kesempatan yang dimiliki. Tersebar luasnya kebenaran (al-ma'ruf) dan terkikis habisnya segala kesalahan (al-munkar) atas dasar keyakinan, bahwa hanya Islam agama yang diterima oleh Allah, menjadi tanggung jawab setiap pribadi Muslim, laki-laki dan perempuan. ${ }^{1}$ Perintah yang terkait dengan kewajiban berdakwah termaktub pada surat an-Nahl ayat 125 .

Kristen (Katolik dan Protestan) sama-sama-berideologi-menerima peranan sebagai "garam dunia" sebagaimana yang terlukiskan dalam perintah pemberitaan Injil: "Karena itu pergilah, jadikanlah semua bangsa murid-Ku dan baptislah mereka dalam nama Bapa dan Anak dan Roh Kudus"'2. Laskar Kristus diperbolehkan menggunakan berbagai macam cara, siasat, dan strategi penyebaran agama yang kesemuanya itu digariskan oleh tuhan Yesus dalam Matius 10:16 "cerdik seperti ular dan tulus hati seperti burung merpati". Prinsip dasar ini sebagai penyemangat dalam perjalanan sejarah Kristen, sebagaimana dalam semboyan extra exclesian nulla salus yang bermakna tidak ada keselamatan di luar gereja (Kristen dan Katolik

Konflik Islam-Kristen seringkali mencuat di permukaan. Misi penyebaran agama, seringkali disebut-sebut sebagai sumber konflik horizontal yang sulit untuk dihindari. Konflik tidak lain adalah efek langsung dari salah satu bentuk dinamika

1 Burhanuddin Daja, Bingkai Teologis Kerukunan dan Upaya Pemasyarakatannya, Agama Dalam Dinamika Sosial Budaya, dalam Abdul Mustaqim dan Robby H. Abror, (Yogyakarta: Insight Reference, 2009), hlm. 19.

2 Matius 28: 19. realita pluralitas. Ketika masyarakat yang berbeda agama atau suku saling berinteraksi, pada saat itu pula kemungkinan terjadinya konflik menjadi sangat terbuka. ${ }^{3}$ Dengan kata lain, konflik dapat terjadi secara alamiah sebagai konsekuensi logis dari perbedaan teologi.

Tantangan hidup beragama pada dewasa ini bertolak pada persoalan kebebasan beragama dan fakta adanya pluralitas agama. Kemajemukan agama mendesak setiap agama untuk berpikir praktis bagaimana bergaul dengan agama lain serta memaknai secara teologis makna kehadiran agama-agama dan kepercayaan itu. Karenanya, sangatlah tidak manusiawi jika segala macam bentuk kekerasan dan paksaan yang datang dari manapun juga bertujuan untuk memaksakan suatu agama kepada orang lain. Sikap saling pengertian itu hanya dapat terwujud dengan pembumian pemaknaan kebebasan beragama yang bernuansa toleransi.

Sejauh pengetahuan peneliti, penelitian yang secara khusus membahas tentang kajian perbandingan antara kebebasan beragama dalam Islam dengan Kristen belum ada yang mengkajinya. Selama ini, penelitian terdahulu yang telah dilakukan hanya meneliti kebebasan beragama dalam perspekif hukum, sosial, dan politik. Penelitian tersebut, antara lain: pertama, tesis yang disusun Abdillah Halim pada tahun 2010 dengan judul "Telaah Politik Hukum dan Kebebasan Beragama Terhadap UU No. 1/PNPS/1965 Tentang Pencegahan Penyalahgunaan Dan/ Atau Penodaan Agama" untuk Program Studi Hukum Islam UIN Sunan Kalijaga Yogyakarta. Penelitian ini menyingkap corak politik di balik penerbitan dan pelestarian UU No. 1/PNPS/1965, karakter hukum, dan pengaruh karakter material hukum UU tersebut terhadap perlindungan kebebasan beragama di Indonesia. Melalui penelitian ini Abdillah Halim menyimpulkan, bahwa

3 Th Sumartana; Noegroho Agoeng; dan Zuly Qodir, Pluralisme, Konflik, dan Perdamaian Studi Bersama Antar Iman, (Yogyakarta: Pustaka Pelajar, 2002), hlm. 9 dan Ali Harb, Nalar Kritis, hlm. 6-7. 
pemerintahan Demokrasi Terpimpin Presiden Soekarno-yang telah mengeluarkan UU No. 1/PNPS/1965-adalah pemerintahan yang bercorak politik otoriter. Oleh karena lahir dari corak politik otoriter, maka karakter hukumnya bersifat represif. UU No. 1/PNPS/1965-tentang pencegahan, penyalahgunaan, dan/atau penodaan agama-disusun secara sentralistik dan lebih mewakili kepentingan penguasa ketika itu dalam rangka menjamin keberlangsungan rezim daripada sungguh-sungguh untuk melindungi dan mewujudkan hak kebebasan beragama manusia. Atau dengan kata lain, undang-undang tersebut digunakan sebagai payung hukum dan pembenar bagi pengawasan negara terhadap agama maupun kepercayaan masyarakat. Perbedaan penelitian Abdillah Halim dengan peneliti terletak pada obyek penelitian. Obyek penelitian Abdillah Halim terletak pada UU No. 1/PNPS/1965, sedang obyek peneliti pada kebebasan beragama dalam Islam dan Kristen.

Kedua, penelitian Hasyim Asy'ari pada tahun 2011 tentang "Politik Hukum Kebebasan Beragama di Indonesia." ${ }^{4}$ Hasyim Asy'ari memaparkan bahwa perkembangan politik hukum kebebasan beragama di Indonesia berjalan tidak linear, namun penuh dinamika sebagaimana pengalaman historis relasi antara negara dan agama yang terjadi selama ini. Relasi antara negara dengan Nahdlatul Ulama (NU) dijadikan model penelitian bagaimana dinamika relasi antara negara dan agama terjadi di Indonesia. Menurut Hasyim Asy'ari, perkembangan politik hukum kebebasan beragama di Indonesia tidak terlepas dari pandangan (persepsi/pemahaman) antara negara dengan masyarakat dan antar warga masyarakat. Penelitian Hasyim Asy'ari mencakup ranah yuridis-normatif, sedang penelitian peneliti mencakup ranah perbandingan agama.

4 Hasyim Asy'ari, Politik Hukum Kebebasan Beragama di Indonesia, dalam Jurnal Hukum Pandecta, Vol. 6, No. 1, Januari 2011, (Semarang: Fakultas Hukum Universitas Diponegoro, 2011), hlm. 1-14.
Ketiga, skripsi Syaefullah tahun 2014 dengan judul "Civil Society dan Kebebasan Beragama di Indonesia: Studi Kasus The Wahid Institute" untuk Fakultas Ilmu Sosial dan Ilmu Politik Universitas Islam Negeri Syarif Hidayatullah Jakarta. Penelitian ini memaparkan bahwa The Wahid Institute merupakan civil society yang konsisten dalam memperjuangkan kebebasan beragama, toleransi, dan nilai-nilai demokrasi. Hal ini terlihat dengan langkah-langkah nyata The Wahid Institute dalam melakukan advokasi hukum dan politik. Penelitian Syaefullah menfokuskan The Wahid Institute sebagai bahan kajiannya, sedang peneliti menfokuskan pada kajian perbandingan agama dengan obyek kajian kebebasan beragama dalam Islam dan Kristen.

Penelitian ini akan membatasi masalahnya dalam kebebasan beragama yang ada dalam dua agama, yakni Islam dan Kristen. Oleh karena itu, penelitian ini akan menjawab pertanyaan-pertanyaan akademik sebagai berikut: Pertama, bagaimana rumusan kebebasan beragama yang terdapat dalam agama Islam dan agama Kristen? Kedua, apa sisi perbedaan dan sisi kesejajaran kebebasan beragama yang terdapat antara agama Islam dengan agama Kristen?

\section{METODE PENELITIAN}

Penelitian ini termasuk dalam penelitian kualitatif dengan ilmu agama sebagai ruang lingkup penelitiannya dan kepustakaan sebagai tempat penelitiannya (library research). Data yang didapat kemudian disajikan secara diskriptif dengan menggunakan pendekatan ilmu sosiologi agama. Sumber data dalam penelitian ini diklasifikasikan ke dalam dua golongan, yaitu data primer dan data sekunder. Data-data dikumpulkan dengan menggunakan teknik dokumentasi dan diuji validitas datanya dengan menerapkan uji confirmability (obyektivitas penelitian). Data yang terkumpul kemudian dianalisis dengan model analisis komparatif dan deduktif.

Teknik analsis datanya menggunakan content analysis dengan menganalisis data 
sesuai dengan kandungan isinya. Dengan ini data-data yang penulis kumpulkankan adalah bersifat deskriptif dan data tekstual yang bersifat fenomenal, maka dalam mengelola data-data tersebut penulis menggunakan analisis ini yaitu dengan cara: a) komparatif, b) deskriptif, dan c) induktif. Selanjutnya, karena penelitian ini merupakan studi tokoh dan sejarah, maka langkah-langkah yang digunakannya meliputi: a) pemilihan topik, b) pengumpulan sumber, c) verifikasi (kritik sejarah, keabsahan sumber), d) interpretasi (analisis dan sintesis), e) historiografi atau penulisan, dan $\mathrm{f}$ ) penyimpulan.

Validitas data diperlukan apabila data yang dilaporkan oleh peneliti tidak berbeda atau sama dengan data yang sesungguhnya terjadi pada objek penelitian. Untuk menguji keabsahan data dalam penelitian kualitatif diperlukan teknik pemeriksaan. Pelaksanaan teknik pemeriksaan didasarkan atas sejumlah kriteria tertentu. Ada empat criteria yang digunakan, yaitu derajat kepercayaan (credibility), keteralihan (transferability), kebergantungan (dependability), dan kepastian (confirmability). ${ }^{5}$ Dalam penelitian ini menggunakan ukuran kepercayaan (credibility), dan keteralihan (transferability). Peneliti menyampaikan secara rinci data-data pendukung dari draft tersebut sehingga terlihat jelas.

Metode lain analisis data dalam penelitian ini adalah induksi dan deduksi. Data-data yang telah diperoleh dalam penelitian ini akan dipelajari dan dikelompokkan sesuai dengan permasalahan. Data-data yang sudah dikelompokkan kemudian dipelajari dan diteliti lagi untuk diambil kesimpulan. Dari metode ini diharapkan dapat menyimpulkan konsep kebebasan beragama dalam Islam dan Kristen.

\section{HASIL DAN PEMBAHASAN}

\section{Kebebasan Beragama dalam Agama Islam}

5 Lexy J. Moleong, Metodologi Penelitian Kualitatif, ( Bandung: PT. Remaja Rosda Karya), hlm. 324. a. Pengertian Kebebasan Beragama

Kebebasan beragama difahami sebagai prinsip bahwa setiap individu bebas memilih dan mengimani agamanya serta mengamalkan sepenuhnya ajaran-ajaran agama yang diyakininya. Islam memberi kebebasan kepada warganya untuk memeluk agama masing-masing dan tidak diperbolehkan memaksakan keyakinannya kepada orang lain. ${ }^{6}$

\section{b. Dasar Kebebasan Beragama}

Perintah untuk menghormati kebebasan beragama dalam agama Islam terdiri dari dua jenis sumber, yakni yang termaktub dalam al-Qur'an-perintah Allah-dan yang berdasarkan hasil konferensi (kesepakatan manusia). Sumber yang berasal dari perintah Allah untuk menghormati kebebasan beragama, terdapat dalam surat al-Baqarah ayat 256; al-Kafirun ayat 6; al-An'am ayat 108; Yunus ayat 99; al-Kahfi ayat 29; dan al-Ghaasyiyah ayat 21-22. Adapun sumber yang berasal dari hasil kesepakatan bersama atas rumusan manusia terdapat dalam piagam Madinah pasal 25, konferensi Geneva, dan dalam pasal 18 Deklarasi Cairo.

\section{c. Batasan Kebebasan Beragama}

1) Islam memberikan kebebasan kepada tiap individu untuk memeluk agama sesuai dengan kepercayaannya dan tidak ada paksaan bagi setiap individu untuk memeluk agama Islam.

2) Setiap Muslim tidak diperkenankan mengganti agama dan keyakinannya tanpa ada alasan yang dapat diterima oleh Islam.

3) Pemeluk agama Islam secara otomatis terikat oleh hukum-hukum yang ada di dalamnya, sehingga tidak diperkenankan membuat ajaran maupun tafsiran-tafsiran baru yang bertentangan dengan dasar-dasar

6 Muhammad Alim, Demokrasi dan Hak Asasi Manusia Dalam Konstitusi Madinah dan UUD 1945, Cet.1, (Yogyakarta: UII Press 2001), hlm.95-96. 
teologis (syariah dan aqidah). ${ }^{7}$

\section{d. Norma Kebebasan Beragama}

Islam telah memiliki norma dan kode etik yang positif-agar tidak menjadikan umat beragama lain sebagai sasaran penyebaran agama - tentang menghormati kebebasan beragama, yakni keyakinan agama tidak boleh (dan memang tidak bisa) dipaksakan "tidak ada paksaan dalam keyakinan agama". ${ }^{8}$ Oleh karena itu, dakwah harus dilakukan dengan kebijaksanaan (hikmah) dengan didikan yang baik-baik (mau'idzah hasanah) dan dengan bertukar pikiran dengan cara yang terbaik (mujadalah billati hiya ahsan). Sesuai dengan kode etik tersebut, umat Kristen dalam pandangan Islam tidak tergolong heiden maupun animis yang masih belum beragama. Umat Kristen dalam Islam disebut sebagai ahli kitab yang mempunyai kedudukan khusus dalam penilaian Islam. ${ }^{9}$

\section{e. Tujuan Kebebasan Beragama}

Implikasi langsung dari tercapainya hak kebebasan beragama tiap individu ialah terwujudkan kerukunan antar umat beragama. Perdamaian sekaligus kerukunan antar umat beragama hanya dapat dicapai, jika masing-masing golongan agama, di samping memelihara identitas masing-masing juga memelihara penghormatan kepada identitas golongan lain (menghormati kebebasan beragama). ${ }^{10}$

\section{Kebebasan Beragama dalam Agama Kristen}

a. Pengertian Kebebasan Beragama

Kebebasan beragama terbentuk ber-

7 Hamid Fahmy Zarkasyi, Islam HAM Dan Kebebasan Beragama, (Jakarta: INSISTS, 2011), hlm. 55-56.

8 Mohammad Natsir, dkk, Surat Kepada Paus Yohanes Paulus II Agar Penyalahgunaan DIAKONIA Dihentikan, (Jakarta: Dewan Da'wah Islamiyah Indonesia Pusat, 1989), hlm. 3.

9 Mohammad Natsir, Mencari Modus Vivendi Antara Ummat Beragama di Indonesia, (Jakarta: Media Dakwah, 1980), hlm. 15.

10 Ibid., hlm 9-10. dasarkan tiga alasan pokok, yaitu: adanya kodrat manusia, sifat iman sejati, dan menyangkut kenegaraan. ${ }^{11}$ Kebebasan beragama bermakna bahwa setiap orang bebas untuk memilih, mengganti, mengamalkan, dan menyiarkan agamanya (atau kepercayaannya) sesuai dengan keyakinannya (suara hatinya). Kebebasan beragama sangatlah penting dan kebebasan tersebut tidak dapat ditolak ataupun dibatasi dengan cara apa pun. ${ }^{12}$ Kebebasannya tersebut-menganut salah satu agama dan mengamalkannya atau tidak - hanya dipertanggungjawabkan kepada Tuhan dan bukan kepada sesama manusia, masyarakat, atau pemerintah mana pun. Tujuan dan arti utama agama adalah supaya manusia dengan bebas mencapai tujuannya, yaitu Tuhan sendiri. Oleh karena itu, hak asasi ini harus dihormati dan tidak boleh diganggu oleh siapa pun dan dengan alasan apa pun.

\section{b. Dasar Kebebasan Beragama}

Dasar kebebasan beragama dalam agama Kristen Katolik tertuang dalam dignitatis humanae-lahir dari Konsili Vatikan II-dan sidang Raya East Asia Christian Conference. Berbeda dengan Katolik, dasar kebebasan beragama dalam gereja Protestan hanya bersifat ekspilisit (hasil tafsiran) dari Alkitab, yakni akibat konsekuensi logis dari pengakuan manusia terhadap citra Allah (imago dei) dan adanya perintah dari Yesus untuk mengasihi sesama manusia seperti mengasihi diri sendiri.

\section{c. Batasan Kebebasan Beragama}

Penggunaan hak atas kebebasan beragama harus diikuti dan dibatasi dengan

11 J. B. Banawiratma, Konteks Berteologi di Indonesia: Buku Penghormatan Untuk HUT ke-70 Prof. Dr. P. D. Latuihamallo, Cet. 2, (Jakarta: Gunung Mulia, 1991), hlm. 252.

12 Pernyataan tersebut dilontarkan oleh Arne Rudvin yang merupakan uskup dari Karachi, United Church of Pakistan. Lihat: Khursid Ahmad; Isma'il Al-Faruqi, Isma'il; dan Muhammad Rasyidi, 1982. Dakwah Islam dan Misi Kristen: Sebuah Dialog Internasional, Edisi ke 1, (Bandung: Risalah, 1984), hlm. 149-152. 
ketaatan pada azas moral tanggung jawab pribadi dan sosial. Maksudnya, dalam menggunakan hak-haknya, setiap manusia maupun kelompok sosial diwajibkan oleh hukum moral untuk memperhatikan dan memperhitungkan hak-hak orang lain, kewajiban dirinya sendiri terhadap orang lain, dan kesejahteraan umum semua orang. Semua orang harus diperlakukan menurut keadilan dan kemanusiaan. ${ }^{13}$

\section{d. Norma Kebebasan Beragama}

Pertemuan perencanaan yang diadakan di Cambesy, Swiss tanggal 12-14 Maret 1979 atas undangan Dewan Gereja Dunia (DGD)-dihadiri perwakilan Islam dan perwakilan Kristen-melahirkan beberapa pinsip atau norma dalam rangka mewujudkan kerukunan hidup bersama atas asas kebebasan beragama. ${ }^{14}$

\section{e. Tujuan Kebebasan Beragama}

Tujuan dari kebebasan beragama ialah mewujudkan kerukunan hidup beragama. Kerukunan hidup antar umat beragama bukan hanya sekedar tidak terjadi permusuhan, pertentangan, ataupun sekedar merukunkan ajaran atau ibadat antar agama. Kerukunan ialah kebersamaan hidup yang saling mencintai, menghargai, dan menumbuhkembangkan. Kerukunan yang sejati akan berimbas langsung dalam terwujudnya perdamaian. Perdamaian bukanlah sebuah keadaan yang tidak ada lagi perbedaan, tapi justru yang menghargai perbedaan. Perdamaian tidak harus semuanya menjadi sama, tetapi saling menghormati.

\section{KESIMPULAN}

Kebebasan beragama dalam Islam dipahami sebagai prinsip bahwa setiap individu bebas memilih dan mengimani agamanya

13 Adolf Heuken SJ, Ensiklopedi Gereja Jilid II H-Konp, Cet. 3, (Jakarta: Yayasan Cipta Loka Caraka, 1992), hlm. 253-254.

14 Olaf Schumann, Dialog Antar Umat Beragama: Di Manakah Kita Berada Kini?, (Jakarta: Lembaga Pelatihan dan Studi-Dewan Gereja-gereja di Indonesia, 1980), hlm. 118-122. serta mengamalkan sepenuhnya ajaran-ajaran agama yang diyakininya. Islam memberi kebebasan kepada warganya untuk memeluk agama masing-masing dan tidak diperbolehkan memaksakan keyakinannya kepada orang lain. Adapun kebebasan beragama dalam Kristen bermakna bahwa setiap orang bebas untuk memilih, mengganti, mengamalkan, dan menyiarkan agamanya (atau kepercayaannya) sesuai dengan keyakinannya (suara hatinya). Kebebasan beragama sangatlah penting dan kebebasan tersebut tidak dapat ditolak ataupun dibatasi dengan cara apa pun.

Kebebasan beragama dalam agama Islam dan kebebasan beragama dalam agama Kristen ketika dikaji dengan metode perbandingan agama, maka akan terlihat sisi-sisi perbedaan dan sisi-sisi kesejajaran. Sisi perbedaan kebebasan beragama dalam Islam dengan Kristen terletak pada: perta$m a$, dasar hukum kebebasan beragama. Islam telah mengatur secara tegas dalam kitab suci (al-Quran) tentang dasar hukum kebebasan beragama. Hal ini berbeda dengan Kristen yang mana pengaturan secara tegas tidak terdapat dalam al-Kitab. Kedua, batas kebebasan beragama. Batas-batas pelaksanaan kebebasan beragama dalam Islam telah diatur secara terperinci dalam al-Quran. Hal ini berbeda dengan Kristen, yang mana batas kebebasan beragama diatur oleh aturan undang-undang atau hukum. Ketiga, norma kebebasan beragama. Norma kebebasan beragama dalam Islam telah diatur dalam al-Quran, sedang dalam Kristen diatur oleh hasil konferensi atau kesepakatan bersama. Adapun sisi kesejajaran kebebasan beragama dalam Islam dan kebebasan beragama dalam Kristen terlihat pada: pertama, pengertian kebebasan beragama yang mana agama Islam dan agama Kristen memaknai kebebasan beragama sebagai hak setiap individu untuk memeluk agama sesuai dengan keyakinannya masing-masing. Kedua, tujuan dari terwujudkan kebebasan beragama, yakni mewujudkan kerukunan antar umat beragama, menciptakan perdamaian, dan menjalankan perintah Tuhan. 


\section{DAFTAR PUSTAKA}

Alim Muhammad. 2001. Demokrasi dan Hak Asasi Manusia Dalam Konstitusi Madinah dan UUD 1945. Cet.1. Yogyakarta: UII Press.

Asy'ari, Hasyim. 2011. Politik Hukum Kebebasan Beragama di Indonesia, dalam Jurnal Hukum Pandecta, Vol. 6, No. 1, Januari 2011. Semarang: Fakultas Hukum Universitas Diponegoro, hlm. 1-14.

Al-Qur'an dan Terjemah New Cordova. 2012. Cet. 1. Jakarta: Syaamil Quran.

Alkitab. 2012. Cetakan Tahun Anggaran Khusus Direktorat Jenderal Bimbingan Masyarakat Kristen Kementerian Agama RI. Jakarta: Lembaga Alkitab Indonesia.

Ahmad, Khursid; Al-Faruqi, Isma'il; dan Rasyidi, Muhammad. 1982. Dakwah Islam dan Misi Kristen: Sebuah Dialog Internasional. Edisi ke 1. Diterjemahkan oleh Z, Ahmad Noer. 1984. Bandung: Risalah.

Banawiratma, J. B. 1991. Konteks Berteologi di Indonesia: Buku Penghormatan Untuk HUT ke-70 Prof. Dr. P. D. Latuihamallo. Cet. 2. Jakarta: Gunung Mulia.

Daja, Burhanuddin. 2009. Bingkai Teologis Kerukunan dan Upaya Pemasyarakatannya. Dalam Abdul Mustaqim dan Abror, Robby H. Agama Dalam Dinamika Sosial Budaya. Yogyakarta: Insight Reference.

Natsir, Mohammad. 1980. Mencari Modus Vivendi Antara Ummat Beragama di Indonesia. Jakarta: Media Dakwah.

dkk. 1989. Surat Kepada Paus Yohanes Paulus II Agar Penyalahgunaan DIAKONIA Dihentikan. Jakarta: Dewan Da'wah Islamiyah Indonesia Pusat.

SJ, Adolf Heuken. 1992. Ensiklopedi Gereja Jilid II H-Konp. Cet. 3. Jakarta: Yayasan Cipta Loka Caraka.

Schumann, Olaf. 1980. Dialog Antar Umat Beragama: Di Manakah Kita Berada Kini?. Jakarta: Lembaga Pelatihan dan Studi-Dewan Gereja-gereja di Indonesia.

Sumartana, Th; Agoeng, Noegroho; dan Qodir, Zuly. 2002. Pluralisme, Konflik, dan Perdamaian Studi Bersama Antar Iman. Yogyakarta: Pustaka Pelajar.

Zarkasyi, Hamid Fahmy. 2011. Islam HAM Dan Kebebasan Beragama. Jakarta: INSISTS. 